\title{
The influence of food histamine intake on asthma activity
}

\author{
Emilia Vassilopoulou ${ }^{1,1}$, George Konstantinou ${ }^{2}$, Anastasia Dimitriou ${ }^{3}$, Yannis Manios ${ }^{4}$, and \\ Nikos Papadopoulos ${ }^{3}$ \\ ${ }^{1}$ International Hellenic University \\ ${ }^{2} 424$ General Military Training Hospital \\ ${ }^{3}$ National and Kapodistrian University of Athens School of Health Sciences \\ ${ }^{4}$ Harokopio University of Athens, Greece
}

July 16, 2020

\begin{abstract}
Background: Asthma is a complex chronic inflammatory disorder, with many factors influencing its prevalence. Diet's impact on the symptoms of the disease is still controversial, although various dietary patterns or specific nutrients have been studied. Objective: The objective of this crossover, randomised, two-period study was to examine the potential of controlling dietary histamine intake and, through this, alter asthma symptoms in children with mild intermittent asthma. Methods: Children with mild intermittent asthma were randomly assigned to either a high- $(\mathrm{HH})$ or low- histamine (LH) diet, based on the Mediterranean pattern, for 4 weeks ( $\mathrm{t} 0$ ). This was followed by a 2-week washout period ( $\mathrm{t} 1$ ) before patients crossed to the alternative diet ( $\mathrm{t} 2$ ) for an additional 4 weeks. Children were assessed at baseline and after the completion of each diet phase. They also recorded symptoms and peak flow throughout the intervention. Adherence to the dietary intervention was assessed via four random 24-hour recalls for each intervention period and comparison of selected qualitative and quantitative indices, i.e. histidine, food choices, energy, macro- and micronutrients intake. Results: Eighteen children (10 boys), with mean age 11,5 $\pm 3,1$ years were recruited and completed the study. A trend for prolonged and more severe symptoms was observed during HH. There was good adherence to the diet during remission periods, but lower compliance during symptomatic periods, particularly for the HH group. The mean actual intake differed significantly between the two diets, not only in the histamine content but also in energy, sugar and various micronutrients, including sodium. Conclusions \& Clinical Relevance: Diet may have an active and direct impact on asthma symptoms. A diet deviating from the Mediterranean standard in terms of high energy, histamine, and salt has been associated with asthma worsening. Dietary interventions in asthmatic patients should be prospectively evaluated for a longer period and with proper nutritional education.
\end{abstract}

\section{Title Page}

The influence of food histamine intake on asthma activity

Emilia Vassilopoulou ${ }^{1}$, George N. Konstantinou ${ }^{2}$, Anastasia Dimitriou ${ }^{3}$, Yiannis Manios ${ }^{4}$, Nikolaos G. Papadopoulos ${ }^{3}$

${ }^{1}$ International Hellenic University, Department of Nutritional Sciences and Dietetics, 57400 Thessaloniki, Greece

${ }^{2}$ Department of Allergy and Clinical Immunology, 424 General Military Training Hospital, Thessaloniki, Greece

3 Allergy Department, 2nd Pediatric Clinic, University of Athens, Athens, Greece.

${ }^{4}$ Department of Nutrition and Dietetics, Harokopio University of Athens, 70 El. Venizelou Avenue, 17671 Kallithea, Greece 


\section{Running title: Food histamine intake on asthma activity}

\section{Corresponding author}

\section{Emilia Vassilopoulou}

International Hellenic University

Department of Nutritional Sciences and Dietetics

57400 Thessaloniki, Greece

vassilopoulouemilia@gmail.com

Word count: 1160

Number of Tables: 3

Material in Electronic Repository: 2 Tables

Main Text

The influence of food histamine intake on asthma activity

Conflict of Interest disclosure statement

All authors have no conflicts of interest to disclose.

\section{Financial Support}

No funding was received for the current research study.

Keywords: asthma; dietary intervention; histamine; Mediterranean diet11

To the editor

Food histamine due to its pharmacological action may be involved in provoking symptoms of wheeze and asthma ${ }^{1}$. The current study aimed to investigate whether controlling dietary histamine intake can interfere with respiratory symptoms in children with mild asthma.

Eighteen children (10 boys; mean age $11.5 \pm 3.1$ years), with mild asthma ${ }^{2}$, were enrolled from an outpatient allergy unit of a tertiary pediatric hospital.

Exclusion criteria were the presence of other chronic or acute diseases (except rhinitis, allergic conjunctivitis or atopic dermatitis), need for current or previous systematic treatment for disorders other than asthma, and food allergy history. Parents provided informed consent and the local ethics committee approved the study.

A two-period, two-intervention, randomized crossover design was followed (Table 1). Participants were randomly assigned (computer-generated random numbers) to start with one out of the two offered diet patterns for four weeks and continue with the other for another four weeks, with a two-week washout period in between, in which they could consume their typical diet without any restriction. One diet was designed as low-histamine ( $\mathrm{LH})$ and the other as high-histamine $(\mathrm{HH})$ in regard to the histamine content of the foods.

Foods from all groups (dairy, fruits, vegetables, starch, meat, fat) were ranked according to their histamine content into low or high histamine. A food list (Table 1), together with four model diet plans based on the Mediterranean diet prototype, one for each week of the 4-week intervention period, were prepared (online repository, Table 2). Patients and their parents were instructed and encouraged to follow these diet plans or modify according to the LH or HH respective food list and alter food portion sizes ad libitum to avoid weight changes. 
Before randomization (t0), participants were evaluated to confirm mild asthma according to GINA ${ }^{3}$ and controlled with low inhaled corticosteroids (fluticasone propionate pMDI 100ug bid). Basic anthropometric measurements (weight and height) were recorded.

Daily symptom scores ${ }^{4}$ were recorded on diary cards throughout the study. Upper airway symptoms included blocked/stuffy nose, runny nose, sneezing/itchy nose, itchy/sore/watery eyes, hoarse voice, and sore throat. Lower airway symptoms included cough and wheezing/noisy breathing during the day, the night and during exercise. Each symptom was scored from 0 (no symptom) to 3 (severely troublesome). A sum of at least 3 score units for either the upper or the lower respiratory symptomatology was considered as a "higher score" day. The quantitative association of symptoms and the comparison between the different dietary intervention periods and the recorded symptom score (upper, lower or total) were evaluated and analyzed.

After the end of the first ( $\mathrm{t} 1$ ) and second ( $\mathrm{t} 2$ ) intervention period, asthma symptom records were re-assessed on-site, and weights were measured. At $\mathrm{t} 1$ guidance for the cross-arm diet plan was provided, for patients to proceed to the second intervention stage after the two weeks washout period. During the intervention periods, four 24 hour recalls were recorded by phone randomly during each diet intervention, to assess compliance and provide assistance for better diet implementation. Histidine intake, which is metabolized to histamine, together with the overall energy, macronutrients and micronutrients were further determined via the 24-diet recalls with the Food-Processor Nutrition Analysis Software ${ }^{5}$. A post-hoc analysis of food choices during the intervention period was performed to evaluate preference changes depending on the provided food lists and symptoms fluctuation.

The distributions of all recorded parameters were assessed with the Shapiro-Wilk test. Descriptive statistics are presented as median (inter-quartile range) for non-normally distributed variables and means \pm standard deviation for normally distributed parameters. The Wilcoxon rank-sum test and Kruskal Wallis tests were used to compare continuous variables and the Pearson's $\mathrm{X}^{2}$ test to compare categorical variables among studied groups. The Wilcoxon matched-pairs rank-sum test was used to compare continuous variables within the same individual between the multiple measurements. All reported p-values are based on 2-sided tests and compared with a significance level of 5\%. Stata 9.1 for Windows (Stata Corp LP, College Station, TX) was used for all statistical calculations and plots.

No loss of asthma control was recorded during the study period. Both upper and lower respiratory symptom scores were lower during the LH period, but the relevant statistical comparisons were not significant. The median number of symptom-free days was higher during the LH diet period as compared to the HH (5.5 days vs 9.5), but again non-significant (p-value=0.753) (Table 3).

Histidine intake was found to be higher in the HH diet (online supplementary, Table 5). Food choices varied among the LH and HH periods as expected. During the HH diet, milk, junk food, juices and vegetables intake was higher at symptom-free days than during the LH diet. At higher score days intake of oils and butter, fish, chocolate, egg and junk food was higher in HH diet than in LH. Fish consumption with the anti-inflammatory n-3 PUFA ${ }^{6}$ was generally low, but increased during days with higher symptom scores independently of the diet assigned, possibly due to caregivers' belief that is a "healthy" choice to relieve symptoms.

Moreover, symptoms fluctuation affected food choices within the same intervention period. In the symptomfree days during the $\mathrm{HH}$ diet, children consumed more starchy foods, olive oil, chocolate, bacon, ham or sausages and junk food, than within days with higher symptoms where they included more fish and butter. Respectively, in the LH symptom-free days, they selected more starchy products, juices from permitted fruit and permitted ham. On the contrary, at higher symptoms days during the LH diet, they consumed more olive oil and fresh fish.

In terms of micronutrients, inadequate intake of vitamin $\mathrm{D}$, correlated previously to pulmonary dysfunction in childhood ${ }^{7}$, potassium, and manganese were noted at all stages of intervention.

Marginally lower intake of calcium and folate compared to the Dietary Reference Intakes (DRIs) ${ }^{8}$ were noted 
during LH. On the other hand, LH diet was superior in beta-carotene, which is an important antioxidant suggested to be directly involved in asthma pathogenesis ${ }^{7}$, as well as in fluoride and vitamin $\mathrm{K}$ intake in comparison to $\mathrm{HH}$ (online repository, Table 5).

A trend towards lower symptoms and more symptom-free days during the LH diet periods revealed. Lack of statistical significance could be explained by the short intervention period, the small sample of participants, the mild symptomatology or the trend for a more "healthy diet" (Table 4) during symptom deterioration periods.

Furthermore, as elucidated from our results, a diet intervention aiming to control a single nutrient's intake may not be feasible unless, as elsewhere shown, this is based on a food supplement or ready-prepared meals to control overall intake ${ }^{9}$. Both these strategies, though, do not reflect the ability of patients to adapt to the proposed changes of eating habits, nor provide the long-term effect of dietary changes. Anyhow, such change is generally difficult to adopt and maintain unless proper therapeutic techniques from medical nutrition therapy are incorporated ${ }^{10}$.

Eating behaviors change in asthmatics during days with symptoms. Whether such change affects clinical outcomes requires further exploration with long-term dietary interventions.

\section{Acknowledgements:}

We would like to express our gratitude to the parents of the children included in the study, for their cooperation during the study and the nurses of the Allergy Clinic for their continuing support.

\section{Impact statement:}

Food choice is affected and/or may affect symptoms in children with mild asthma. Diet intervention is promising yet challenging, for asthma control.

\section{Signature}

Emilia Vassilopoulou, $\mathrm{PhD}{ }^{1}$, George N. Konstantinou, $\mathrm{MD}, \mathrm{PhD}^{2}$, Anastasia Dimitriou, $\mathrm{MD}^{3}$, Yiannis Manios, $\mathrm{PhD}^{4}$, Nikolaos G. Papadopoulos, $\mathrm{MD}, \mathrm{PhD}^{3}$

${ }^{1}$ International Hellenic University, Department of Nutritional Sciences and Dietetics, 57400 Thessaloniki, Greece

${ }^{2}$ Department of Allergy and Clinical Immunology, 424 General Military Training Hospital, Thessaloniki, Greece

${ }^{3}$ Allergy Department, 2nd Pediatric Clinic, University of Athens, Athens, Greece.

${ }^{4}$ Department of Nutrition and Dietetics, Harokopio University of Athens, 70 El. Venizelou Avenue, 17671 Kallithea, Greece

\section{References}

1. Reese I, Ballmer-Weber B, Beyer K, et al. Leitlinie zum vorgehen bei verdacht auf unverträglichkeit gegenüber oral aufgenommenem histamin: Leitlinie der deutschen gesellschaft für allergologie und klinische immunologie (DGAKI), der gesellschaft für pädiatrische allergologie und umweltmedizin (GPA. Allergo J. 2017;26(2):51-6111. doi:10.1007/s40629-017-0011-5

2. Papadopoulos NG, Arakawa H, Carlsen KH, et al. International consensus on (ICON) pediatric asthma. Allergy . 2012;67(8):976-997. doi:10.1111/j.1398-9995.2012.02865.x

3. Pocket guide for Asthma management and prevention (for Adults and Children Older than 5 Years. https://ginasthma.org/wp-content/uploads/2019/04/GINA-2019-main-Pocket-Guide-wms.pdf. Accessed July $2^{\text {nd }}, 2020$.

4. Konstantinou GN, Xepapadaki P, Manousakis E, et al. Assessment of airflow limitation, airway inflammation, and symptoms during virus-induced wheezing episodes in 4- to 6-year-old children. $J$ Allergy Clin Immunol . 2013;131(1). doi:10.1016/j.jaci.2012.10.033 
5. Esha Research. Food Processor Nutrition Analysis Software. https://esha.com/products/foodprocessor/. Accessed July $2^{\text {nd }}, 2020$

6. Li J, Xun P, Zamora D, et al. Intakes of long-chain omega-3 (n-3) PUFAs and fish in relation to incidence of asthma among American young adults: The CARDIA study. Am J Clin Nutr . 2013;97(1):173-178. doi:10.3945/ajcn.112.041145

7. Nagel G, Linseisen J. Dietary intake of fatty acids, antioxidants and selected food groups and asthma in adults'. Eur J Clin Nutr. 2005;59(1):8-15. doi:10.1038/sj.ejcn.1602025

8. DRI Dietary Reference Intakes, https://www.ncbi.nlm.nih.gov/books/NBK222890/. Accessed July $2^{\text {nd }}, 2020$

9. Guilleminault L, Williams EJ, Scott HA, Berthon BS, Jensen M, Wood LG. Diet and Asthma: Is It Time to Adapt Our Message?. Nutrients . 2017;9(11):1227. Published 2017 Nov 8. doi:10.3390/nu9111227

10. Vassilopoulou E, Efthymiou D, Elissavet V, Agorastos A. When weight loss is not self-motivated: Cognitive behavioral and medical nutrition therapy for weight management in a case of idiopathic intracranial hypertension. Integr Food Nutr Metab . 2019. doi:10.15761/IFNM.1000255

Table 1: Food ranking in low and high histamine content

\begin{tabular}{ll}
\hline Food group/ Type of diet & Low Histamine \\
\hline Dairy products & Plain milk without additives (cow's or goat's), butter, plain yogurt, ricotta cheese, cottage \\
Fruit & Apple, apricot, peach, pear, melon \\
Vegetables & Asparagus, cabbage, lettuce, green beans, onion, pepper, radish, turnip \\
Legumes & Peas, lentils, chickpeas \\
Starchy products/grains & Bread with natural yeast without preservatives, oat cereals, pure corn flakes, potato, sweet \\
Nuts & Chestnut, sunflower seeds, pine nuts, pistachios, almonds, coconuts, currants, red currants, \\
Spices & Herbs, spices except for anise, red pepper, curry (ready-made spicy products not allowed) \\
Meat/poultry/fish & Beef, chicken without skin, turkey without skin, fresh fish, lamb, rabbit, veal, cooked eggs, \\
Fats/ oils & All vegetable oils, homemade sauces prepared with permitted ingredients \\
Beverages & homemade lemonade \\
Sweets/sweeteners & Sugar, homemade jams, homemade sweets with permitted ingredients \\
\hline
\end{tabular}

Table 3 Comparisons between the median number of days with symptoms and median symptom score during the two intervention periods.

Data are presented as median (interquartile range).

\begin{tabular}{|c|c|c|c|c|}
\hline & & Type of diet & Type of diet & \\
\hline & & Low Histamine & High Histamine & p-values \\
\hline $\begin{array}{l}\text { Symptoms } \\
\text { duration in } \\
\text { days }\end{array}$ & $\begin{array}{l}\text { Symptoms } \\
\text { duration in } \\
\text { days }\end{array}$ & $5.5(8)$ & $9.5(4)$ & 0.753 \\
\hline \multirow{3}{*}{$\begin{array}{l}\text { Respiratory } \\
\text { Symptoms }\end{array}$} & Upper* & $4.67(11.5)$ & $12.5(5.83)$ & 0.780 \\
\hline & Lower* & $4.25(13.1)$ & $14(12.45)$ & 0.727 \\
\hline & Total* & $11.33(53.5)$ & $30.17(21.42)$ & 0.889 \\
\hline
\end{tabular}

* units in symptom score scale

** comparisons between different types of diets (Wilcoxon matched-pairs sign test)

Table 4 Food choices according to symptoms fluctuation during and among the two intervention periods 


\begin{tabular}{|c|c|c|c|c|c|c|c|c|}
\hline & $\begin{array}{l}\text { LH } \\
\text { period }\end{array}$ & $\begin{array}{l}\text { LH } \\
\text { period }\end{array}$ & & $\begin{array}{l}\text { HH } \\
\text { period }\end{array}$ & $\begin{array}{l}\text { HH } \\
\text { period }\end{array}$ & & $\begin{array}{l}\text { HH vs } \\
\text { LH }\end{array}$ & $\begin{array}{l}\text { HH vs } \\
\text { LH }\end{array}$ \\
\hline & Remission & Episode & $\mathrm{p}$-value ${ }^{1}$ & Remission & Episode & p-value ${ }^{1}$ & $\begin{array}{l}\text { Remission } \\
\text { p-value }\end{array}$ & $\begin{array}{l}\text { Episode } \\
\text { p-value }\end{array}$ \\
\hline Milk & $\begin{array}{l}1.74 \\
( \pm 1.38)\end{array}$ & $\begin{array}{l}2.69 \\
( \pm 1.21)\end{array}$ & 0.064 & $\begin{array}{l}2.69 \\
( \pm 1.98)\end{array}$ & $\begin{array}{l}3.77 \\
( \pm 1.35)\end{array}$ & 0.133 & 0.004 & 0.107 \\
\hline $\begin{array}{l}\text { Starchy } \\
\text { food }\end{array}$ & $3.65(2.94)$ & $6.04(2.72)$ & 0.021 & $4.61(3.28)$ & $\begin{array}{l}6.27 \\
( \pm 1.85)\end{array}$ & 0.046 & 0.972 & 0.141 \\
\hline Meat & $\begin{array}{l}4.01 \\
( \pm 2.91)\end{array}$ & $\begin{array}{l}5.19 \\
( \pm 2.32)\end{array}$ & 0.382 & $\begin{array}{l}3.25 \\
( \pm 2.05)\end{array}$ & $4.4( \pm 1.78)$ & 0.133 & 0.196 & 0.207 \\
\hline Olive oil & $\begin{array}{l}3.24 \\
( \pm 3.12)\end{array}$ & $\begin{array}{l}0.26 \\
( \pm 0.44)\end{array}$ & 0.014 & $\begin{array}{l}0.28 \\
( \pm 0.44)\end{array}$ & $\begin{array}{l}4.23 \\
( \pm 3.16)\end{array}$ & 0.002 & 0.002 & 0.007 \\
\hline Butter & $\begin{array}{l}0.318 \\
( \pm 0.83)\end{array}$ & $\begin{array}{l}0.05 \\
( \pm 0.14)\end{array}$ & 0.299 & $\begin{array}{l}2.56 \\
( \pm 2.62)\end{array}$ & $0.46( \pm 0.5)$ & 0.043 & 0.014 & 0.007 \\
\hline Fish & $\begin{array}{l}0.51 \\
( \pm 0.89)\end{array}$ & $\begin{array}{l}0.75 \\
( \pm 0.59)\end{array}$ & 0.184 & $3.7( \pm 2.93)$ & $\begin{array}{l}0.29 \\
( \pm 0.47)\end{array}$ & 0.003 & 0.059 & 0.003 \\
\hline Chocolate & $\begin{array}{l}0.268 \\
( \pm 0.7)\end{array}$ & $\begin{array}{l}0.28 \\
( \pm 0.45)\end{array}$ & 0.657 & $0.9( \pm 0.74)$ & $\begin{array}{l}3.33 \\
( \pm 3.06)\end{array}$ & 0.007 & 0.002 & 0.015 \\
\hline Egg & $\begin{array}{l}0.05 \\
( \pm 0.15)\end{array}$ & $\begin{array}{l}0.04 \\
( \pm 0.08)\end{array}$ & 0.809 & $\begin{array}{l}0.89 \\
( \pm 1.47)\end{array}$ & $\begin{array}{l}0.18 \\
( \pm 0.34)\end{array}$ & 0.053 & 0.027 & 0.006 \\
\hline Sweats & $0.74( \pm 0.8)$ & $1.12( \pm 1.1)$ & 0.328 & $\begin{array}{l}1.55 \\
( \pm 1.34)\end{array}$ & $\begin{array}{l}1.46 \\
( \pm 1.08)\end{array}$ & 0.861 & 0.463 & 0.123 \\
\hline Nuts & $0.67( \pm 1.3)$ & $0.4( \pm 0.42)$ & 0.528 & $\begin{array}{l}0.61 \\
( \pm 1.39)\end{array}$ & $\begin{array}{l}0.09 \\
( \pm 0.19)\end{array}$ & 0.426 & 0.035 & 0.514 \\
\hline $\begin{array}{l}\text { Bacon or } \\
\text { sausages or } \\
\text { ham }\end{array}$ & $\begin{array}{l}0.11 \\
( \pm 0.18)\end{array}$ & $\begin{array}{l}5.08 \\
( \pm 3.21)\end{array}$ & 0.002 & $\begin{array}{l}0.31 \\
( \pm 1.11)\end{array}$ & $\begin{array}{l}0.71 \\
( \pm 0.46)\end{array}$ & 0.030 & 0.002 & 0.242 \\
\hline Junk food & $\begin{array}{l}1.01 \\
( \pm 1.27)\end{array}$ & $\begin{array}{l}0.89 \\
( \pm 1.15)\end{array}$ & 0.889 & $0.12( \pm 0.3)$ & $\begin{array}{l}2.03 \\
( \pm 1.41)\end{array}$ & 0.002 & 0.055 & 0.017 \\
\hline Fried oil & $\begin{array}{l}0.79 \\
( \pm 1.25)\end{array}$ & $\begin{array}{l}0.14 \\
( \pm 0.13)\end{array}$ & 0.726 & $\begin{array}{l}1.23 \\
( \pm 1.59)\end{array}$ & $\begin{array}{l}1.26 \\
( \pm 0.94)\end{array}$ & 0.917 & 0.003 & 0.105 \\
\hline Juices & 0 & $0.8(0.76)$ & 0.004 & $0.15(0.56)$ & $0.12(0.2)$ & 0.155 & 0.016 & 0.317 \\
\hline Fruit & $\begin{array}{l}0.29 \\
( \pm 0.37)\end{array}$ & $\begin{array}{l}0.82 \\
( \pm 0.61)\end{array}$ & 0.546 & $\begin{array}{l}1.27 \\
( \pm 2.35)\end{array}$ & $\begin{array}{l}0.59 \\
( \pm 0.49)\end{array}$ & 0.726 & 0.221 & 0.302 \\
\hline Vegetables & $\begin{array}{l}0.66 \\
( \pm 1.02)\end{array}$ & $0.1( \pm 0.23)$ & 0.052 & $0.4( \pm 0.51)$ & $\begin{array}{l}0.95 \\
( \pm 0.79)\end{array}$ & 0.028 & 0.002 & 0.806 \\
\hline
\end{tabular}

Values are presented in mean ( \pm standard deviation)

Comparisons (Wilcoxon matched-pairs rank-sum test) of food choices

${ }^{1}$ during episodes vs. remission periods within the same intervention period

2 during remission between the two intervention periods

${ }^{3}$ during episodes between the two intervention periods

ONLINE REPOSITORY

Table 2: Model weekly diet plan provided to the patients for the LH and HH period of the dietary intervention 


\begin{tabular}{lll}
\hline Low Histamine & Low Histamine & Low Histamine \\
\hline Breakfast & 1 cup of whole fat milk +2 whole wheat homemade chocolate biscuits & 1 cup whole milk+ 1slice of whole \\
Snack & 1 cup melon & 1 cup of fresh mixed apple-pear \\
Lunch & 1 portion green fresh beans +1 slice of whole wheat bread+ potatoes & 1 portion stuffed zucchini or pepp \\
Snack & Oven-baked apple with egg and breadcrumbs, sugar and cinnamon & 1 milkshake with whole fat milk, \\
Dinner & Caesars Chicken salad with lettuce, boiled corn, cucumber, olive oil & 1 chicken burger with whole whea \\
\hline
\end{tabular}

\begin{tabular}{|c|c|c|c|c|c|c|c|}
\hline $\begin{array}{l}\text { High } \\
\text { Histamine }\end{array}$ & $\begin{array}{l}\text { High } \\
\text { Histamine }\end{array}$ & $\begin{array}{l}\text { High } \\
\text { Histamine }\end{array}$ & $\begin{array}{l}\text { High } \\
\text { Histamine }\end{array}$ & $\begin{array}{l}\text { High } \\
\text { Histamine }\end{array}$ & $\begin{array}{l}\text { High } \\
\text { Histamine }\end{array}$ & $\begin{array}{l}\text { High } \\
\text { Histamine }\end{array}$ & $\begin{array}{l}\text { High } \\
\text { Histamine }\end{array}$ \\
\hline Breakfast & $\begin{array}{l}1 \text { cup of } \\
\text { whole fat } \\
\text { milk+ } \\
2 \text { whole } \\
\text { wheat } \\
\text { homemade } \\
\text { chocolate } \\
\text { biscuits }\end{array}$ & $\begin{array}{l}1 \text { cup } \\
\text { whole } \\
\text { milk+ } \\
1 \text { slice of } \\
\text { whole } \\
\text { wheat } \\
\text { bread }+ \\
1 \text { tsp } \\
\text { Nutella }\end{array}$ & $\begin{array}{l}1 \text { cup of } \\
\text { milk } \\
\text { choco- } \\
\text { late+ } 2 \\
\text { homemade } \\
\text { vanilla } \\
\text { biscuits }\end{array}$ & $\begin{array}{l}1 \text { cup of } \\
\text { milk }+1 \\
\text { whole } \\
\text { wheat } \\
\text { bread }+ \\
1 \text { tsp } \\
\text { honey }\end{array}$ & $\begin{array}{l}1 \text { whole } \\
\text { fat yogurt } \\
\text { with fruit }\end{array}$ & $\begin{array}{l}1 \text { whole } \\
\text { fat milk }+ \\
\frac{1}{2} \text { cup corn } \\
\text { flakes }\end{array}$ & $\begin{array}{l}1 \text { whole } \\
\text { fat milk+ } \\
2 \text { slices of } \\
\text { toasted } \\
\text { bread+ } \\
2 \text { tsp } \\
\text { straw- } \\
\text { berry } \\
\text { jam }\end{array}$ \\
\hline Snack & $\begin{array}{l}1 \text { cup of } \\
\text { fresh } \\
\text { orange } \\
\text { juice }\end{array}$ & $\begin{array}{l}1 \text { cup of } \\
\text { mixed } \\
\text { fresh fruit } \\
\text { juice }\end{array}$ & 1 banana & $\begin{array}{l}1 \text { cup } \\
\text { anana } \\
\text { juice }\end{array}$ & 1 banana & $\begin{array}{l}1 \text { kiwi } \\
\text { fruit }\end{array}$ & $\begin{array}{l}1 \text { cup of } \\
\text { fresh } \\
\text { orange- } \\
\text { anana } \\
\text { juice }\end{array}$ \\
\hline Lunch & $\begin{array}{l}1 \text { portion of } \\
\text { lentils+ } \\
\text { mature } \\
\text { yellow } \\
\text { cheese } \\
\text { (Cretian } \\
\text { graviera)+ } \\
\text { 1slice of } \\
\text { wholewheat } \\
\text { bread }\end{array}$ & $\begin{array}{l}1 \text { portion } \\
\text { stuffed } \\
\text { tomatoes } \\
\text { with rice } \\
\text { and mince } \\
\text { meat+ 1slice } \\
\text { of } \\
\text { wholewheat } \\
\text { bread+ feta } \\
\text { cheese }\end{array}$ & $\begin{array}{l}1 \text { portion of } \\
\text { fish sticks+ } \\
\text { 1boiled } \\
\text { potato+ } \\
\text { cauliflower } \\
\text { or broccoli }\end{array}$ & $\begin{array}{l}1 \text { portion } \\
\text { "tourlou" } \\
\text { vegetables } \\
\text { (aubergine, } \\
\text { carrots, } \\
\text { cucumber, } \\
\text { tomato, } \\
\text { olive oil, } \\
\text { potatoes)+ } \\
1 \text { slice whole } \\
\text { wheat bread }\end{array}$ & $\begin{array}{l}1 \text { portion } \\
\text { pasta with } \\
\text { tomato } \\
\text { sauce and } \\
\text { mush- } \\
\text { rooms+ } \\
\text { parmesan } \\
\text { cheece+ } \\
\text { Tomato } \\
\text { salad }\end{array}$ & $\begin{array}{l}4-5 \text { fried } \\
\text { meatballs+ } \\
15-20 \text { slices } \\
\text { of fried } \\
\text { potatoes+ } \\
\text { broccoli or } \\
\text { cauliflower }\end{array}$ & $\begin{array}{l}1 \text { portion } \\
\text { spinach with } \\
\text { rice and } \\
\text { tomato+ } \\
\text { feta cheese+ } \\
1 \text { slice of } \\
\text { whole wheat } \\
\text { bread }\end{array}$ \\
\hline Snack & $\begin{array}{l}1 \text { yogurt } \\
\text { with } \\
\text { chocolate } \\
\text { slices }\end{array}$ & $\begin{array}{l}\text { Homemade } \\
\text { Banana } \\
\text { milkshake } \\
\text { (banana, } \\
\text { whole } \\
\text { milk, } \\
\text { honey) }\end{array}$ & $\begin{array}{l}\text { Fruit } \\
\text { salad: } \\
\text { grapes, } \\
\text { orange, } \\
\text { banana }\end{array}$ & $\begin{array}{l}1 \text { cup } \\
\text { strawber- } \\
\text { ries or } \\
\text { grapes }\end{array}$ & $\begin{array}{l}\text { chocolate } \\
\text { ice cream }\end{array}$ & $\begin{array}{l}50 \text { gr milk } \\
\text { or back } \\
\text { chocolate }\end{array}$ & $\begin{array}{l}\text { Lemon or } \\
\text { straw- } \\
\text { berry } \\
\text { Sorbet }\end{array}$ \\
\hline
\end{tabular}




\begin{tabular}{|c|c|c|c|c|c|c|c|}
\hline $\begin{array}{l}\text { High } \\
\text { Histamine }\end{array}$ & $\begin{array}{l}\text { High } \\
\text { Histamine }\end{array}$ & $\begin{array}{l}\text { High } \\
\text { Histamine }\end{array}$ & $\begin{array}{l}\text { High } \\
\text { Histamine }\end{array}$ & $\begin{array}{l}\text { High } \\
\text { Histamine }\end{array}$ & $\begin{array}{l}\text { High } \\
\text { Histamine }\end{array}$ & $\begin{array}{l}\text { High } \\
\text { Histamine }\end{array}$ & $\begin{array}{l}\text { High } \\
\text { Histamine }\end{array}$ \\
\hline Dinner & $\begin{array}{l}1 \text { piece of } \\
\text { ham and } \\
\text { cheese pie }\end{array}$ & $\begin{array}{l}1 \text { burger } \\
\text { with pork } \\
\text { mince } \\
\text { neat_- } \\
\text { tomato } \\
\text { salad }\end{array}$ & $\begin{array}{l}1 \text { hot dog: } \\
\text { whole } \\
\text { wheat } \\
\text { bread, } 1 \\
\text { sausage } \\
\text { stuffed } \\
\text { with } \\
\text { cheese, } \\
1 \text { tsp } \\
\text { mustard, } \\
1 \text { tsp } \\
\text { ketchup }\end{array}$ & $\begin{array}{l}1 \text { souvlaki } \\
\text { with pork } \\
\text { meat and } \\
\text { whole } \\
\text { wheat pita } \\
\text { bread, } \\
\text { fried } \\
\text { potatoes, } \\
\text { tomato }\end{array}$ & $\begin{array}{l}\text { Chef } \\
\text { salad: } \\
\text { Roquefort } \\
\text { cheese, } \\
\text { salami, } \\
\text { cedar, } \\
\text { boiled egg, } \\
\text { tomato, } \\
\text { lettuce, } \\
\text { olive il }\end{array}$ & $\begin{array}{l}1 \text { slice of } \\
\text { spinach } \\
\text { pie }\end{array}$ & $\begin{array}{l}\text { Baked } \\
\text { pork meat } \\
\text { with } \\
\text { Greek } \\
\text { salad }\end{array}$ \\
\hline
\end{tabular}

Table 5. Comparison of micronutrient intake (mean values) with Dietary Reference Intake (DRI).

\begin{tabular}{lllllll}
\hline Type of diet & Sodium $(\mathbf{m g})$ & Potassium $(\mathbf{m g})$ & Calcium $(\mathbf{m g})$ & Iron $(\mathbf{m g})$ & Phosphorus $(\mathbf{m g})$ & Magnes \\
\hline High Histamine & $\mathbf{3 2 0 0}$ & 2922 & 1365 & 14.5 & 1603 & 280 \\
Low Histamine & 1808 & 2557 & 807 & 12 & 1208 & 240 \\
DRI & 1500 & 4500 & 1300 & 8 & 1250 & 240 \\
\hline
\end{tabular}

\begin{tabular}{llllll}
\hline & Vitamin A (RE) & Vitamin C (mg) & Vitamin D (ug) & Vitamin E (IU) & Thiamin (mg) \\
\hline High Histamine & 737 & 84 & $\mathbf{4 . 5}$ & 11.6 & 2 \\
Low Histamine & 627 & 46 & $\mathbf{4 . 4 6}$ & 10.4 & 1.26 \\
DRI & 600 & 45 & $\mathbf{1 5}$ & 11 & 0.9 \\
\hline
\end{tabular}

Deficient intake in specific nutrients is marked in bold letters. 